\title{
Effect of Consciousness Energy Healing Treatment on the Metal Profile and Properties of Tellurium
}

\author{
Mahendra Kumar Trivedi ${ }^{1}$, Alice Branton ${ }^{1}$, Dahryn Trivedi ${ }^{1}$ and Snehasis Jana ${ }^{2 *}$ \\ ${ }^{1}$ Trivedi Global, Inc., USA \\ ${ }^{2}$ Trivedi Science Research Laboratory Pvt Ltd., India
}

Submission: March 01, 2021; Published: March 22, 2021

"Corresponding author: Snehasis Jana, Trivedi Science Research Laboratory Pvt Ltd., Thane (W), Maharashtra, India

\begin{abstract}
Tellurium metal which known to have many applications in metals, semiconductors, telecommunication industries. In this study, the impact of the impact of the Trivedi Effect ${ }^{\circledR}$-Consciousness Energy Healing Treatment on the physicochemical properties of tellurium powder was evaluated using modern analytical techniques. The tellurium metal powder was divided into two parts defined as the control and Biofield Energy Treated sample. The control sample did not receive the Biofield Energy Treatment; however, the Biofield Treated sample received the Biofield Treatment (the Trivedi Effect ${ }^{\circledR}$ ) by a well-known Biofield Energy Healer, Mr. Mahendra Kumar Trivedi remotely. The powder XRD peak intensities and the crystallite sizes of tellurium powder sample were significantly altered ranging from $-52.53 \%$ to $-29.03 \%$ and $-5.32 \%$ to $56.51 \%$, respectively than control tellurium. While the average crystallite size of Biofield Treated tellurium was significantly increased by $21.37 \%$ compared with the control sample. The particle size values in the treated tellurium were significantly increased at $\mathrm{d}_{10}, \mathrm{~d}_{50}, \mathrm{~d}_{90}$, and $\mathrm{D}(4,3)$ by $22.24 \%, 26.00 \%, 12.92 \%$, and $17.78 \%$, respectively than control tellurium. Thus, the specific surface area of Biofield Energy Treated tellurium powder $(0.362 \mathrm{~m} 2 / \mathrm{g})$ was significantly decreased by $18.65 \%$ compared with the control sample $(0.445 \mathrm{~m} 2 / \mathrm{g})$. Overall results envisaged that Biofield Energy Healing Treatment might have generates a new polymorphic form of tellurium which would show better thermal stability and powder flowability compared with the control sample. The Trivedi Effect ${ }^{\circledR}$ Treated tellurium would be very useful for the metal industry (in iron, stainless steel, copper, and lead alloys), cadmium telluride solar panels, pigments for ceramics, glass optical fibers for telecommunications, vulcanization of rubber, blasting caps, tellurite agar to identify members of the Corynebacterium, catalysts for the heterogeneous reactions, production of iodine-131 by neutron bombardment, etc.
\end{abstract}

Keywords: Tellurium; Consciousness energy healing treatment; The trivedi effect ${ }^{\circledR}$; PXRD; Particle size; TGA/DTG

\section{Introduction}

Tellurium (Te) is a chemical element present in the Earth's crust only in about 0.001 parts per million. It is found combined in the minerals like calaverite, sylvanite, and tellurite. The tellurium allotrope crystalline form is silvery-white with a metallic luster, brittle, and can be easily pulverized; however, the amorphous allotropic form is black-brown powder [1]. ${ }^{120} \mathrm{Te},{ }^{122} \mathrm{Te},{ }^{123} \mathrm{Te}$, ${ }^{124} \mathrm{Te},{ }^{125} \mathrm{Te},{ }^{126} \mathrm{Te},{ }^{128} \mathrm{Te}$, and ${ }^{130} \mathrm{Te}$ are the eight naturally available isotopes of tellurium. The tellurium has no biological function established properly, but some of the organism like fungi utilize it instead of sulfur and selenium into amino acids such as tellurocysteine and telluro-methionine [2]. Many bacteria, such as Pseudomonas aeruginosa and yeast also use it for a different purpose $[3,4]$. The electrical conductivity of tellurium high, thus it is used as a semiconductor [5]. Tellurium has many industrial applications, i.e., to improve their strength and hardness of metals (in iron, stainless steel, copper, and lead alloys), cadmium telluride ( $\mathrm{CdTe}$ ) is used for the solar panels, glass optical fibers for telecommunications, pigments for ceramics, vulcanization of rubber, blasting caps. Tellurite agar used for the identification of Corynebacterium diphtheria. It is also used as a catalyst for the heterogeneous reactions and production of iodine- 131 by neutron bombardment, etc. [6-12]. It is very toxic and teratogenic which disturbs the development of an embryo or fetus. Personnel exposed to very small quantities $\left(0.01 \mathrm{mg} / \mathrm{m}^{3}\right)$ of tellurium in the air develop "tellurium breath", which has a garlic-like odor [1]. Tellurium is soluble in nitric acid, aqua regia, potassium cyanide, potassium hydroxide, and sulfuric acid, whereas it is insoluble in hot \& cold water, and hydrochloric acid [12]. 
The physicochemical properties of metal play a very important role in manufacturing and other industrial purposes. It was scientifically proven by many experiments that the Trivedi Effect $^{\circledR}{ }_{-}$ Biofield Energy Healing Treatment has the significant impact on the particle size, surface area, chemical and thermal properties of metals, ceramics, etc. [13-15]. The Trivedi Effect ${ }^{\circledR}$ is a natural and only scientifically proven phenomenon in which an individual can harness this inherently intelligent energy from the "Universe" and transmit it anywhere on the planet through the possible mediation of neutrinos [16]. There is a unique infinite, para-dimensional electromagnetic energy field exists surrounding each and every living organism's body known as the "Biofield". The Biofield based Energy Healing Therapies have been reported to have significant performance curing various disease [17]. The National Institutes of Health (NIH) and the National Center for Complementary and Alternative Medicine (NCCAM) applaud and included the Energy therapy under Complementary and Alternative Medicine (CAM) category along with other complementary therapies (i.e., Yoga, Ayurveda, Reiki, etc.) which has been accepted by the most of the U.S.A. people $[18,19]$. The outstanding outcome of the Trivedi Effect $^{\circledR}$-Consciousness Energy Healing Treatment also on polymers $[20,21]$, nutraceuticals [22,23], pharmaceuticals [24-26], organic compounds [27-29], cancer cells [30,31], microorganisms [32,33], and crops $[34,35]$ have been widely reported with scientifically experimental data. Therefore, one such experiment was designed to determine the impact of the Trivedi Effect ${ }^{\circledR}$-Consciousness Energy Healing Treatment on the physicochemical properties of tellurium metal powder using modern analytical techniques.

\section{Materials and Methods}

\section{Chemicals and reagents}

Tellurium metal powder was purchased from Sigma Aldrich (USA) and other chemicals required during the experiments were purchased from India.

\section{Consciousness energy healing treatment strategies}

The tellurium metal powder sample was divided into two parts and termed as a control and the Biofield Energy Treated sample. One control sample did not receive the Biofield Energy Treatment was provided but it was treated with a "sham" healer. The "sham" healer did not have any knowledge about the Biofield Energy and the Biofield Energy Treatment. However, the second part of tellurium so called the Biofield Energy Treated sample received the Trivedi Effect $^{\circledR}$-Consciousness Energy Healing Treatment remotely under standard laboratory conditions for 3 minutes through the healer's unique energy transmission process by the renowned Biofield Energy Healer, Mahendra Kumar Trivedi, USA. After the treatment, both the samples were kept in sealed conditions and characterized using modern analytical techniques.

\section{Characterization of tellurium}

\section{Powder X-ray Diffraction (PXRD) analysis}

The powder X-ray diffraction analysis of the test samples (control and Biofield Energy Treated tellurium metal powder) was performed with the help of Rigaku MiniFlex-II Desktop X-ray diffractometer (Japan) [36,37]. The size of the individual crystal was calculated from XRD data using the Scherrer's formula (1)

$$
G=k \lambda / \beta \cos \theta
$$

Where $\mathrm{k}$ is the equipment constant, $\mathrm{G}$ is the crystallite size in $\mathrm{nm}, \lambda$ is the radiation wavelength, $\beta$ is the full-width at half maximum, and $\theta$ is the Bragg angle [38].

The \% change in peak intensity, crystallite size, and average crystallite size of tellurium was calculated using the following equation 2:

$$
\% \text { change }=\frac{[\text { Treated }- \text { Control }]}{\text { Control }} \times 100
$$

\section{Particle size analysis (PSA)}

The particle size analysis of tellurium metal powder was conducted on Malvern Mastersizer 2000, the UK using wet method $[39,40]$. The $d(0.1) \mu \mathrm{m}, \mathrm{d}(0.5) \mu \mathrm{m}, \mathrm{d}(0.9) \mu \mathrm{m}$ represent particle diameter corresponding to $10 \%, 50 \%$, and $90 \%$ of the cumulative distribution. $\mathrm{D}(4,3)$ represents the average massvolume diameter, and SSA is the specific surface area $\left(\mathrm{m}^{2} / \mathrm{g}\right)$. The calculations were done by using software Mastersizer Ver. 5.54. The $\%$ change in the surface area and particle size for tellurium at below $10 \%$ level $\left(d_{10}\right), 50 \%$ level $\left(d_{50}\right), 90 \%$ level $\left(d_{90}\right)$, and $D(4,3)$ was calculated using the following equation 2 .

\section{Results and Discussion}

\section{Powder X-ray Diffraction (PXRD) analysis}

The powder XRD diffractograms of the test samples (control and Biofield Energy Treated tellurium powder) showed sharp and intense peaks (Figure 1) indicated that both the samples were crystalline in nature. The control and Biofield Energy Treated tellurium showed the highest peak intensity at $2 \theta$ equal to $27.45^{\circ}$ and $27.66^{\circ}$, respectively (Table 1 , entry 3 ). The peak intensities of the Biofield Energy Treated tellurium were altered ranging from $-52.53 \%$ to $-29.03 \%$ compared with the control sample. Similarly, the crystallite sizes of the Biofield Energy Treated tellurium sample were significantly altered in the range from $-5.32 \%$ to $56.51 \%$ compared to the control sample. Though, the average crystallite size of the Biofield Energy Treated tellurium was significantly increased by $21.37 \%$ compared with the control sample.

The variations in the crystallite sizes and peak intensities indicated some modification happened in the crystal properties in the Biofield Energy Treated tellurium compared than control tellurium. The peak intensity of each diffraction face of the crystal changes according to the crystal morphology [41], and alterations in the crystal size pattern provide the proof of polymorphic transitions $[42,43]$. The Trivedi Effect ${ }^{\circledR}$ is believed to have potential to alter the status of proton and neutrons in the nucleus of an element. Therefore, the Trivedi Effect ${ }^{\circledR}$-Consciousness Energy Healing Treatment probably introduced a new polymorphic form of tellurium via neutrino oscillation [16]. As per different 
scientific study different polymorphic forms of a compound have the significant effects on the thermodynamic and physicochemical properties like melting point, stability, and solubility are different from the parent form $[44,45]$. Thus, it can be anticipated that the Biofield Energy Treated tellurium would be better for the industrial applications.

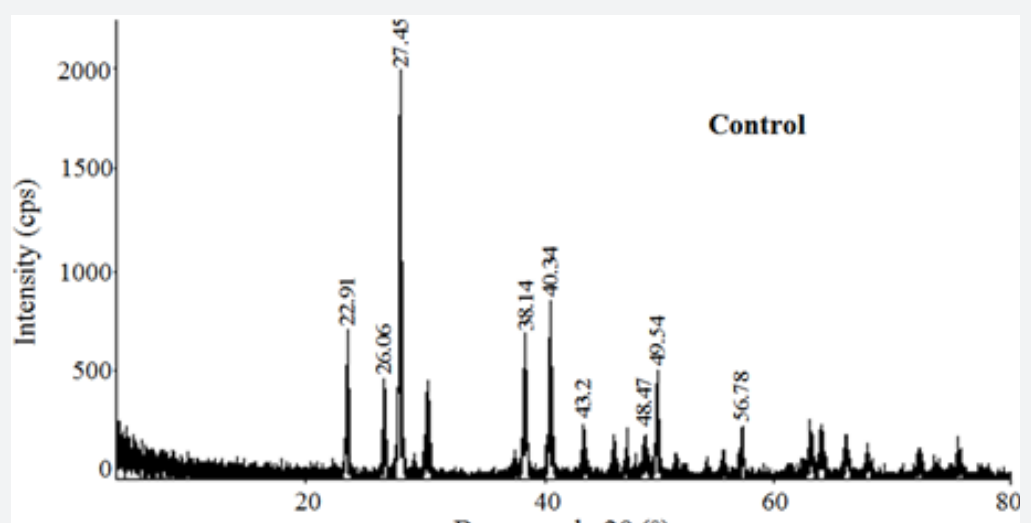

Bragg angle $2 \theta\left(^{\circ}\right)$

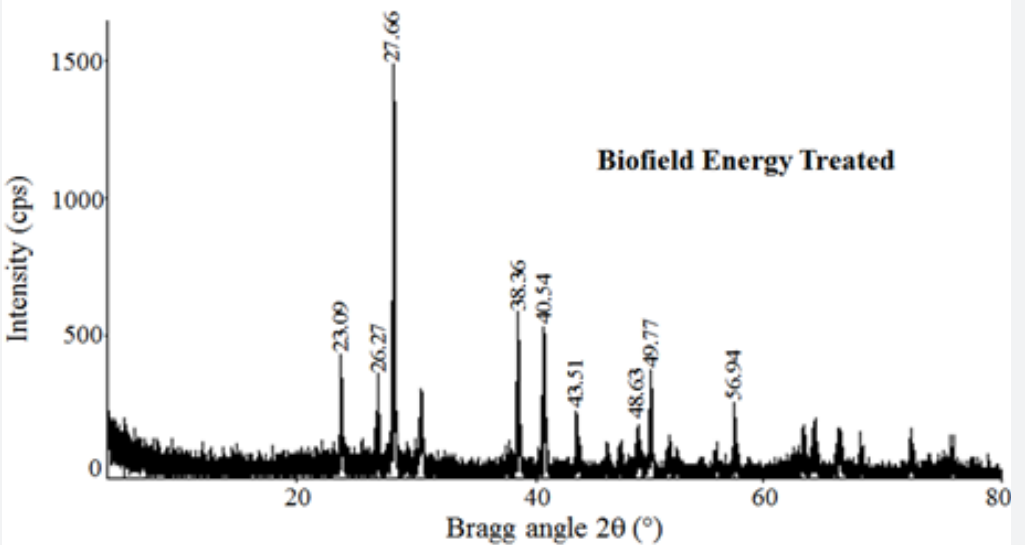

Figure 1: PXRD diffractograms of the control and Biofield Energy Treated tellurium.

Table 1: PXRD data for the control and Biofield Energy Treated tellurium.

\begin{tabular}{|c|c|c|c|c|c|c|c|c|}
\hline \multirow{2}{*}{ Entry No. } & \multicolumn{2}{|c|}{ Bragg angle $\left({ }^{\circ} 2 q\right)$} & \multicolumn{3}{|c|}{ Peak Intensity (\%) } & \multicolumn{3}{|c|}{ Crystallite size $(\mathrm{G}, \mathrm{nm})$} \\
\hline & Control & Treated & Control & Treated & $\%$ change $^{a}$ & Control & Treated & $\%$ change $^{\mathrm{b}}$ \\
\hline 1 & 22.91 & 23.09 & 99 & 47 & -52.53 & 338 & 491 & 45.27 \\
\hline 2 & 26.06 & 26.27 & 61 & 29 & -52.46 & 354 & 473 & 33.62 \\
\hline 3 & 27.45 & 27.66 & 350 & 218 & -37.71 & 336 & 442 & 31.55 \\
\hline 4 & 38.14 & 38.36 & 135 & 87 & -35.56 & 351 & 417 & 18.8 \\
\hline 5 & 40.34 & 40.54 & 152 & 83 & -45.39 & 330 & 366 & 10.91 \\
\hline 6 & 43.2 & 43.51 & 31 & 22 & -29.03 & 292 & 457 & 56.51 \\
\hline 7 & 48.47 & 48.63 & 39 & 21.5 & -44.87 & 259 & 294 & 13.51 \\
\hline 8 & 49.54 & 49.77 & 74 & 49.2 & -33.51 & 376 & 356 & -5.32 \\
\hline 9 & 56.78 & 56.94 & 35 & 19 & -45.71 & 468 & 568 & 21.37 \\
\hline 10 & 67.53 & 67.89 & 21.9 & 12.1 & -44.75 & 406 & 396 & -2.46 \\
\hline 11 & & & age crystal & & & 351 & 426 & 21.37 \\
\hline
\end{tabular}

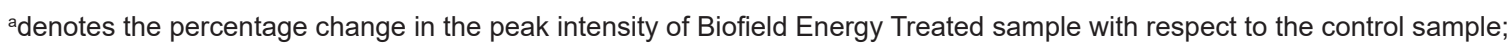

${ }^{b}$ denotes the percentage change in the crystallite size of Biofield Energy Treated sample with respect to the control sample. 


\section{Particle size analysis (PSA)}

The particle size distribution data of both the control and Biofield Energy Treated tellurium powder are presented in Table 2. The particle size values of the control tellurium powder at $d_{10}, d_{50}, d_{90}$, and $D(4,3)$ were $6.29 \mu \mathrm{m}, 21.3 \mu \mathrm{m}, 64.46 \mu \mathrm{m}$, and $29.16 \mu \mathrm{m}$, respectively. Moreover, the particle sizes of the Biofield Treated tellurium powder at $\mathrm{d}_{10}, \mathrm{~d}_{50}, \mathrm{~d}_{90}$, and $\mathrm{D}(4,3)$ were $7.68 \mu \mathrm{m}$, $27.02 \mu \mathrm{m}, 72.79 \mu \mathrm{m}$, and $34.35 \mu \mathrm{m}$, respectively. Consequently, the particle size values in the Biofield Energy Treated tellurium were significantly increased at $\mathrm{d}_{10}, \mathrm{~d}_{50}, \mathrm{~d}_{90^{\prime}}$, and $\mathrm{D}(4,3)$ by $22.24 \%, 26 . \%$, $12.92 \%$, and $17.78 \%$, respectively compared to the control sample.
Therefore, the specific surface area of Biofield Energy Treated tellurium powder $\left(0.362 \mathrm{~m}^{2} / \mathrm{g}\right)$ was significantly decreased by $18.65 \%$ compared with the control sample $\left(0.445 \mathrm{~m}^{2} / \mathrm{g}\right)$. From the results, it was anticipated that the Trivedi Effect ${ }^{\circledR}$-Consciousness Energy Healing Treatment might be acting like an energy mill which increased the size of the particles; hence increased the surface area of the Biofield Energy Treated tellurium compared to the control sample. The increased particle size of tellurium definitely improves the physicochemical and thermal behaviour. Thus, the Biofield Energy Treated tellurium might offer better flowability and thermal stability compared to the control sample.

Table 2: Particle size distribution of the control and Biofield Energy Treated tellurium.

\begin{tabular}{|c|c|c|c|c|c|}
\hline Parameter & $\mathbf{d}_{\mathbf{1 0}}(\boldsymbol{\mu m})$ & $\mathbf{d}_{\mathbf{5 0}}(\boldsymbol{\mu m})$ & $\mathbf{d}_{\mathbf{9 0}}(\boldsymbol{\mu m})$ & $\mathbf{D}(\mathbf{4}, \mathbf{3})(\boldsymbol{\mu m})$ & $\mathbf{S S A}\left(\mathbf{m}^{\mathbf{2}} / \mathbf{g}\right)$ \\
\hline Control & 6.29 & 21.3 & 64.46 & 29.16 & 0.445 \\
\hline Biofield Treated & 7.68 & 27.02 & 72.79 & 34.35 & 0.362 \\
\hline Percent change* $(\%)$ & 22.24 & 26.86 & 12.92 & 17.78 & -18.65 \\
\hline
\end{tabular}

$d_{10}, d_{50}$, and $d_{90}$ : particle diameter corresponding to $10 \%, 50 \%$, and $90 \%$ of the cumulative distribution, $D(4,3)$ : the average mass-volume diameter, and SSA: the specific surface area.

*denotes the percentage change in the Particle size distribution of the Biofield Energy Treated sample with respect to the control sample.

\section{Conclusion}

The Biofield Treatment (the Trivedi Effect ${ }^{\circledR}$ ) showed significant effects on the peak intensities, crystallite size, particle size, surface area, and thermal properties of tellurium powder. The powder XRD peak intensities and the crystallite sizes of tellurium powder sample were significantly altered ranging from $-52.53 \%$ to $-29.03 \%$ and $-5.32 \%$ to $56.51 \%$, respectively compared with the control tellurium. While the average crystallite size of the Biofield Energy Treated tellurium was significantly increased by $21.37 \%$ compared with the control sample. The particle size values in the treated tellurium were significantly increased at $\mathrm{d}_{10}, \mathrm{~d}_{50}, \mathrm{~d}_{90}$, and $\mathrm{D}(4,3)$ by $22.24 \%, 26 . \%, 12.92 \%$, and $17.78 \%$, respectively compared with the control sample. Therefore, the specific surface area of the treated tellurium powder $\left(0.362 \mathrm{~m}^{2} / \mathrm{g}\right)$ was significantly decreased by $18.65 \%$ compared with the control sample $\left(0.445 \mathrm{~m}^{2} / \mathrm{g}\right)$. Overall, the study findings concluded that the Biofield Treatment might have generates a new polymorphic form of tellurium, which would show better thermal stability and powder flowability as compared with the control sample. The Trivedi Effect ${ }^{\circledR}$ Treated tellurium would be very useful for the metal industry (in iron, stainless steel, copper, and lead alloys), cadmium telluride solar panels, pigments for ceramics, glass optical fibers for telecommunications, blasting caps, vulcanization of rubber, tellurite agar to identify members of the Corynebacterium, catalysts for the heterogeneous reactions, production of iodine- 131 by neutron bombardment, etc.

\section{Acknowledgement}

The authors are grateful to Central Leather Research Institute, SIPRA Lab. Ltd., Trivedi Science, Trivedi Global, Inc., Trivedi Testimonials, and Trivedi Master Wellness for their assistance and support during this work.

\section{References}

1. https://en.wikipedia.org/wiki/Tellurium

2. Shadia ER, Razak AA, Ragab AM, El-Meleigy M (1989) Incorporation of tellurium into amino acids and proteins in a tellurium-tolerant fungi. Biol Trace Elem Res 20(3): 225-232.

3. Chua SL, Sivakumar K, Rybtke M, Yuan M, Andersen JB, et al. (2015) C-di-GMP regulates Pseudomonas aeruginosa stress response to tellurite during both planktonic and biofilm modes of growth. Sci Rep 5: 10052 .

4. Ottosson LG, Logg K, Ibstedt S, Sunnerhagen P, Käll M, et al. (2010) Sulfate assimilation mediates tellurite reduction and toxicity in Saccharomyces cerevisiae. Eukaryotic Cell 9: 1635-1647.

5. Isaakovich BL (1997) Tellurium. Semiconductor materials. CRC Press. pp. 89-91.

6. Vasilis MF, Chul KH, Erik A (2008) Emissions from photovoltaic life cycles. Environ Sci Technol 42(6): 2168-2174.

7. Zweibel $\mathrm{K}(2010)$ The Impact of tellurium supply on cadmium telluride photovoltaics. Science 328(5979): 699-701.

8. Nishii J, Morimoto S, Inagawa I, Iizuka R, Yamashita T, Yamagishi $T$ (1992) Recent advances and trends in chalcogenide glass fiber technology: A review. J Non-Cryst Solids 140: 199-208. 
9. Maurice M (1987) Sulfur and Related Elements. Rubber Technology. Springer. p. 42.

10. Kwantes W (1984) Diphtheria in Europe. J Hyg 93(3): 433-437.

11. Kazuhiko A, Yury VK, Alberto V, Manfred ES, István CL, et al. (2013) Multifunctionality of crystalline $\operatorname{MoV}(\mathrm{TeNb}) \mathrm{M} 1$ oxide catalysts in selective oxidation of propane and benzyl alcohol. ACS Catalysis 3(6): 1103-1113.

12. http://www.nordion.com/wp-content/uploads/2014/10/MI Iodine-131_Solution_Canada.\%20pdf

13. Dabhade VV, Tallapragada RMR, Trivedi MK (2009) Effect of external energy on the atomic, crystalline, and powder characteristics of antimony and bismuth powders. Bulletin of Materials Science 32: 471479.

14. Trivedi MK, Tallapragada RM (2008) A transcendental to changing metal powder characteristics. Met Powder Rep 63(9): 22-28.

15. Nayak G, Trivedi MK, Branton A, Trivedi D, Jana S (2018) The physicochemical and thermal properties of consciousness energy healing treated silver oxide $\left(\mathrm{Ag}_{2} \mathrm{O}\right)$. Aspects in Mining \& Mineral Science 2: 1-6.

16. Trivedi MK, Mohan TRR (2016) Biofield energy signals, energy transmission and neutrinos. American Journal of Modern Physics 5: 172-176.

17. Rubik B, Muehsam D, Hammerschlag R, Jain S (2015) Biofield science and healing: history, terminology, and concepts. Glob Adv Health Med 4: 8-14.

18. Barnes PM, Bloom B, Nahin RL (2008) Complementary and alternative medicine use among adults and children: United States, 2007. Nat Health Stat Report 12: 1-23.

19. Koithan M (2009) Introducing complementary and alternative therapies. J Nurse Pract 5(1): 18-20.

20. Nayak G, Trivedi MK, Branton A, Trivedi D, Jana S (2018) Evaluation of the physicochemical and thermal properties of consciousness energy healing treated polylactic-co-glycolic acid (PLGA). Journal of Food Science and Technology 5(3): 117-125.

21. Nayak G, Trivedi MK, Branton A, Trivedi D, Jana S (2018) Physicochemical and thermal properties of consciousness energy healing treated hydroxypropyl $\beta$-cyclodextrin. Med \& Analy Chem Int J 2: 000124

22. Nayak G, Trivedi MK, Branton A, Trivedi D, Jana S (2018) Impact of Consciousness energy healing treatment on the physicochemica and thermal properties of vitamin $\mathrm{D}_{3}$ (cholecalciferol). Food Sci Nutr Technol 3: 000162.

23. Nayak G, Trivedi MK, Branton A, Trivedi D, Jana S (2018) Evaluation of the consciousness energy healing treated berberine chloride using PXRD, PSA, and DSC Analysis. Food Sci Nutr Technol 3(6): 000168.

24. Nayak G, Trivedi MK, Branton A, Trivedi D, Jana S (2018) Consciousness energy healing treatment: Impact on physicochemical and therma properties of silver sulfadiazine. Journal of advanced pharmaceutical science and technology 2:1-13

25. Trivedi MK, Patil S, Shettigar H, Bairwa K, Jana S (2015) Effect of biofield treatment on spectral properties of paracetamol and piroxicam. Chem Sci J 6: 98.

26. Trivedi MK, Patil S, Shettigar H, Singh R, Jana S (2015) An impact of biofield treatment on spectroscopic characterization of pharmaceutical compounds. Mod Chem Appl 3: 159.

27. Trivedi MK, Branton A, Trivedi D, Nayak G, Saikia G, et al. (2015) Physical and structural characterization of biofield treated imidazole derivatives. Nat Prod Chem Res 3: 187.
28. Trivedi MK, Branton A, Trivedi D, Nayak G, Sethi KK, et al. (2016) Evaluation of isotopic abundance ratio in biofield energy treated nitrophenol derivatives using gas chromatography-mass spectrometry. American Journal of Chemical Engineering 4(3): 68-77.

29. Trivedi MK, Branton A, Trivedi D, Nayak G, Panda P, et al. (2016) Determination of isotopic abundance of ${ }^{13} \mathrm{C} /{ }^{12} \mathrm{C}$ or ${ }^{2} \mathrm{H} /{ }^{1} \mathrm{H}$ and ${ }^{18} \mathrm{O} /{ }^{16} \mathrm{O}$ in biofield energy treated 1-chloro-3-nitrobenzene (3-CNB) using gas chromatography-mass spectrometry. Science Journal of Analytical Chemistry 4: 42-51.

30. Trivedi MK, Patil S, Shettigar H, Gangwar M, Jana S (2015) In vitro evaluation of biofield treatment on cancer biomarkers involved in endometrial and prostate cancer cell lines. J Cancer Sci Ther 7: 253257.

31. Trivedi MK, Patil S, Shettigar H, Mondal SC, Jana S (2015) The potential impact of biofield treatment on human brain tumor cells: A time-lapse video microscopy. J Integr Oncol 4: 141.

32. Trivedi MK, Patil S, Shettigar H, Mondal SC, Jana S (2015) In vitro Evaluation of Biofield Treatment on Enterobacter cloacae: Impact on Antimicrobial Susceptibility and Biotype. J Bacteriol Parasitol 6: 241.

33. Trivedi MK, Patil S, Shettigar H, Mondal SC, Jana S (2015) Evaluation of biofield modality on viral load of Hepatitis B and C Viruses. J Antivir Antiretrovir 7: 083-088.

34. Trivedi MK, Branton A, Trivedi D, Nayak G, Mondal SC, et al. (2015) evaluation of plant growth, yield and yield attributes of biofield energy treated mustard (Brassica juncea) and chick pea (Cicer arietinum) seeds. Agriculture, Forestry and Fisheries 4: 291-295.

35. Trivedi MK, Branton A, Trivedi D, Nayak G, Gangwar M, et al. (2015) Agronomic characteristics, growth analysis, and yield response of biofield treated mustard, cowpea, horse gram, and groundnuts. International Journal of Genetics and Genomics 3(6): 74-80.

36. (1997) Desktop X-ray Diffractometer "MiniFlex+". The Rigaku Journal 14: 29-36.

37. Zhang T, Paluch K, Scalabrino G, Frankish N, Healy AM, et al. (2015) Molecular structure studies of (1S,2S)-2-benzyl-2,3-dihydro-2(1Hinden-2-yl)-1H-inden-1-ol. J Mol Struct 1083: 286-299.

38. Langford JI, Wilson AJC (1978) Scherrer after sixty years: A survey and some new results in the determination of crystallite size. J Appl Cryst 11: 102-113.

39. Trivedi MK, Sethi KK, Panda P, Jana S (2017) A comprehensive physicochemical, thermal, and spectroscopic characterization of zinc (II) chloride using Xray diffraction, particle size distribution, differential scanning calorimetry, thermogravimetric analysis/ differential thermogravimetric analysis, ultravioletvisible, and Fourier transforminfrared spectroscopy. International Journal of Pharmaceutical Investigation 7: 33-40.

40. Trivedi MK, Sethi KK, Panda P, Jana S (2017) Physicochemical, thermal and spectroscopic characterization of sodium selenate using XRD, PSD, DSC, TGA/DTG, UV-vis, and FT-IR. Marmara Pharmaceutical Journal 21/2: 311-318.

41. Inoue M, Hirasawa I (2013) The relationship between crystal morphology and XRD peak intensity on $\mathrm{CaSO}_{4} \cdot 2 \mathrm{H}_{2} \mathrm{O}$. J Crystal Growth 380: 169-175.

42. Raza K, Kumar P, Ratan S, Malik R, Arora S (2014) Polymorphism: The phenomenon affecting the performance of drugs. SOJ Pharm Pharm Sci 1: 10 .

43. Brittain HG (2009) Polymorphism in pharmaceutical solids in Drugs and Pharmaceutical Sciences, volume 192, $2^{\text {nd }}$ Edn, Informa Healthcare USA, Inc., New York. 
44. Censi R, Martino PD (2015) Polymorph Impact on the Bioavailability and Stability of Poorly Soluble Drugs. Molecules 20(10): 18759-18776.

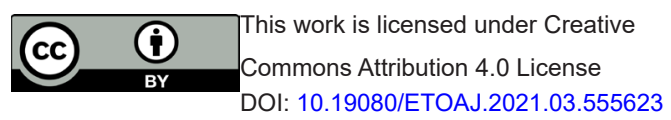

45. Blagden N, de Matas M, Gavan PT, York P (2007) Crystal engineering of active pharmaceutical ingredients to improve solubility and dissolution rates. Adv Drug Deliv Rev 59(7): 617-630.

\author{
Your next submission with Juniper Publishers \\ will reach you the below assets \\ - Quality Editorial service \\ - Swift Peer Review \\ - Reprints availability \\ - E-prints Service \\ - Manuscript Podcast for convenient understanding \\ - Global attainment for your research \\ - Manuscript accessibility in different formats \\ ( Pdf, E-pub, Full Text, Audio)
}

- Unceasing customer service

Track the below URL for one-step submission https://juniperpublishers.com/online-submission.php 